\title{
Quellen und Literatur
}

\section{Archivquellen}

Benutzt wurden Quellen aus folgenden Beständen (genaue Aktensignatur s. Fußnoten):

Politisches Archiv des Auswärtigen Amts (PA AA), Berlin
B 1
Ministerbüro
B 2
Büro Staatssekretäre
B 8
Protokollabteilung
B 30
Vereinte Nationen
B 36
Länderreferate Naher und Mittlerer Osten
B 37
Länderreferate Asien
B 38
Berlin und Wiedervereinigungsfragen
B 45
Menschenrechte, Humanitäre Hilfe
B 57
Verkehr, Tourismus, Wirtschaftsfragen der Verteidigung
B 58
Wirtschaftliche Zusammenarbeit, Entwicklungshilfe
B 80
Völkerrecht, Staatsverträge, Rechtsfragen im Gefolge der deutschen Einigung
B 81 Gesandtschafts- und Konsularrecht, Wiedergutmachung, Verkehrsrecht
B 84 Zivilrecht, Handelsrecht
B $90 \quad$ Kulturpolitik Grundsatzangelegenheiten
B 96 Kulturinstitute, Kulturgesellschaften
B 97 Länderreferate bilaterale Kulturpolitik
B 110 Organisation
B 130 VS-Registraturen
B 150 Edition „Akten zur Auswärtigen Politik der Bundesrepublik Deutschland“
DHAK Botschaft Dhaka
ISLA Botschaft Islamabad
KALK Generalkonsulat Kalkutta
NEWD Botschaft New Delhi
M 1 Zentralarchiv
M 2 B-Bestand
M 35 Süd- und Südostasien
M92 Archiv

Bundesarchiv (BArch), Koblenz, Berlin-Lichterfelde, Freiburg i.Br.

B 102 Bundesministerium für Wirtschaft

B 122 Bundespräsidialamt

B 136 Bundeskanzleramt

B 213 Bundesministerium für wirtschaftliche Zusammenarbeit und Entwicklung

BW $1 \quad$ Bundesministerium der Verteidigung

DA $1 \quad$ Volkskammer der DDR

DA 5 Staatsrat der DDR

DC 20 Ministerrat der DDR

O Open Access. (C) 2020 Alexander Benatar, publiziert von De Gruyter. (ㄷ) BY-Nc-ND Dieses Werk ist lizenziert unter der Creative Commons Attribution-NonCommercial-NoDerivatives 4.0 Lizenz. 

DC 20-I/4
Beschluss- und Sitzungsreihe des Präsidiums des Ministerrates
DL 2 Ministerium für Außenhandel und Innerdeutschen Handel
DY 13 Liga für Völkerfreundschaft der DDR
DY 30
Sozialistische Einheitspartei Deutschlands
DZ 9
Friedensrat der DDR

Archiv des Bundesbeauftragten für die Unterlagen des Staatssicherheitsdienstes der ehemaligen Deutschen Demokratischen Republik (BStU), Berlin

MfS, HV A Ministerium für Staatssicherheit, Hauptverwaltung Aufklärung

MfS, HA PS Ministerium für Staatssicherheit, Hauptabteilung Personenschutz

MfS, SdM Sekretariat des Ministers

National Archives of India (NAI), Neu-Delhi

Ministry of External Affairs

Nehru Memorial Museum \& Library (NMML), Neu-Delhi

P. N. Haksar Papers

\section{Gedruckte Quellen}

Auswärtiges Amt / Institut für Zeitgeschichte (Hrsg.): Akten zur Auswärtigen Politik der Bundesrepublik Deutschland. Bde. 1970 bis 1972. München: R. Oldenbourg 2001-2003.

Bayerlacher, Wolfgang / Lindner, Roland / Schwiesau, Hermann: Die DDR in der Region Süd- und

Südostasien. In: Siegfried Bock / Ingrid Muth / Hermann Schwiesau (Hrsg.): DDR-Außenpolitik im Rückspiegel. Diplomaten im Gespräch. Münster: Lit Verlag 2004, S. 282-306.

Brandt, Willy: Erinnerungen. Frankfurt a. M.: Propyläen 1989.

Diehl, Günter: Die indischen Jahre. Erfahrungen eines deutschen Botschafters. Frankfurt a. M.:

Societäts-Verlag 1991.

Fischer, Herbert: DDR - Indien. Ein Diplomat berichtet. Berlin (Ost): Staatsverlag der DDR 1984.

-: Entwicklung der staatlichen und gesellschaftlichen Beziehungen DDR - Indien. In: Joachim

Heidrich (Hrsg.): DDR - Indien: Partner auf Zeit. Erfahrungen und Einsichten. Hamburg:

Lit-Verlag 1998, S. 24-46.

Heidrich, Joachim: Indien in Politik und Wissenschaft der DDR. In: Ders. (Hrsg.): DDR - Indien:

Partner auf Zeit. Erfahrungen und Einsichten. Hamburg: Lit-Verlag 1998, S. 250-275.

Heß, Peter: Bangladesch. Tragödie einer Staatsgründung. Frauenfeld / Stuttgart: Verlag Huber 1972.

Linde, Gerd: Bangla Desh. Indien und die Großmächte im Pakistanischen Konflikt. Stuttgart:

Kohlhammer 1972.

Matinuddin, Kamal: Tragedy of Errors. East Pakistan Crisis, 1968-1971. Lahore: Wajidalis 1994.

Muth, Ingrid / Seidel, Karl: Außenpolitische Interessen der DDR. In: Siegfried Bock / Ingrid Muth / Hermann Schwiesau (Hrsg.): DDR-Außenpolitik im Rückspiegel. Diplomaten im Gespräch. Münster: Lit Verlag, 2004, S. 13-32.

Niazi, Amir Abdullah Khan: The Betrayal of East Pakistan. Karachi: Oxford University Press 1998.

Siddiqui, Kalim: Conflict, Crisis and War in Pakistan. New York / Washington: Praeger Publishers 1972.

Singh, Sheelendra K.: Bangla Desh Documents, Bd. 2. Dhaka: The University Press Limited (UPL) 1999. 


\section{Forschungsliteratur}

Abmeier, Angela: Kalte Krieger am Rio de la Plata? Die beiden deutschen Staaten und die argentinische Militärdiktatur (1976-1983). Düsseldorf: Droste 2017.

Al-Farooq, Thimo: Bangladesch = Tod der Two Nation Theory? In: derFreitag, 18.06.2016. https://www.freitag.de/autoren/talrooq/bangladesch-tod-der-two-nation-theory (Zugriff am 08.10.2018).

Ali, S. Mahmud: Understanding Bangladesh. London: Columbia/Hurst 2010.

Bajpai, Kanti: India's Regional Disputes. In: Bruce Jones / Pratap Bhanu Mehta / Waheguru Pal Singh Sidhu (Hrsg.): Shaping the Emerging World. India and the Multilateral Order. Washington, D.C.: Brookings Institution Press 2013, S. 115-130.

Bange, Oliver: Sicherheit und Staat. Die Bündnis- und Militärpolitik der DDR im internationalen Kontext 1969 bis 1990. Berlin: Christoph Links 2017

Barnds, William J.: India, Pakistan and the Great Powers. New York / Washington / London: Praeger Publishers 1972.

Bass, Gary J.: The Blood Telegram: Nixon, Kissinger, and a Forgotten Genocide. New York: Knopf 2013.

-: Bargaining away Justice. India, Pakistan, and the International Politics of Impunity for the Bangladesh Genocide. In: International Security 41,2 (2016), S. 140-187.

Bauerkämper, Arnd / Sabrow, Martin / Stöver, Bernd: Die doppelte deutsche Zeitgeschichte. In: Dies. (Hrsg.): Doppelte Zeitgeschichte. Deutsch-deutsche Beziehungen 1945-1990. Bonn: Dietz 1998, S. 9-16.

Bayly, Christopher A. / Beckert, Sven / Connelly, Matthew / Hofmeyr, Isabel et al.: AHR Conversation: On Transnational History. In: The American Historical Review 111,5 (2006), S. 1441-64.

Bergmann, David: The Politics of Bangladesh's Genocide Debate. In: The New York Times, 05.04.2016, http://www.nytimes.com/2016/04/06/opinion/the-politics-of-bangladeshs-genocide-debate.html?r=0 (Zugriff am 08.10.2018).

Bhaskar, Chitrapu Uday: Russia-India-China meeting shows a multipolar world order is taking shape. In: South China Morning Post, 15.12.2017, https://www.scmp.com/comment/ insight-opinion/article/2124329/russia-india-china-meeting-shows-multipolar-world-order (Zugriff am 08.10.2018).

Blickle, Paul / Abdi-Herrle, Sasan: Der neue Kalte Krieg. In: Zeit Online, 07.06.2016, https:// www.zeit.de/politik/ausland/2016-07/nato-aufruestung-russland-kraefteverhaeltniskarte (Zugriff am 08.10.2018).

Bösch, Frank: Geteilt und verbunden. Perspektiven auf die deutsche Geschichte seit den 1970er Jahren. In: Ders. (Hrsg.): Geteilte Geschichte. Ost- und Westdeutschland 1970-2000. Göttingen: Vandenhoeck \& Ruprecht 2015, S. 7-37.

Booz, Rüdiger Marco: „Hallsteinzeit. “ Deutsche Außenpolitik 1955-1972. Bonn: Bouvier 1995.

Bose, Sarmila: Dead Reckoning. Memories of the 1971 Bangladesh War. London: Hurst \& Co. 2011.

-: The Question of Genocide and the Quest for Justice in the 1971 War. In: Journal of Genocide Research 13,4 (2011), S. 393-419.

Bresselau v. Bressensdorf, Agnes / Seefried, Elke: Introduction. West Germany and the Global South in the Cold War Era. In: Agnes Bresselau v. Bressensdorf / Elke Seefried / Christian F. Ostermann (Hrsg.): West Germany, the Global South and the Cold War. Berlin / Boston: De Gruyter Oldenbourg 2017, S. 7-24 
Brunner, Detlev / Grashoff, Udo / Kötzing, Andreas: Asymmetrisch verflochten? Einleitung. In: Dies. (Hrsg.): Asymmetrisch verflochten? Neue Forschungen zur gesamtdeutschen Nachkriegsgeschichte. Berlin: Christoph Links 2013, S. 11-17.

Chatterjee, Anubha: Indiens Politik während des letzten indisch-pakistanischen Krieges (Dezember 1971) und seine Rolle bei der Entstehung von Bangladesch. München: tuduv 1992.

Chen, Jian: Mao's China and the Cold War. Chapel Hill: University of North Carolina Press 2001.

Chopra, Pran N.: Ostbengalen - Eine Krise für Indien. Eine Darstellung aus indischer Sicht. In: Europa-Archiv. Zeitschrift für Internationale Politik. Bonn: Deutsche Gesellschaft für Auswärtige Politik 26 (1971), S. 608-616.

Chowdhury, M. Abdul Mu'min: Behind the Myth of Three Million. London: Al-Hilal Publishers Ltd. 1996.

Clavin, Patricia: Defining Transnationalism. In: Contemporary European History 14,4 (2005), S. 421-439

Conrad, Sebastian: What Is Global History? Princeton, NJ: Princeton University Press 2016.

Das Gupta, Amit: Handel, Hilfe, Hallstein-Doktrin. Die deutsche Südasienpolitik unter Adenauer und Erhard 1949-1966. Husum: Matthiesen 2004.

-: Südasien und der Wettbewerb der Supermächte 1954-1972. In: Bernd Greiner / Christian Th. Müller / Dierk Walter (Hrsg.): Heiße Kriege im Kalten Krieg. Studien zum Kalten Krieg, Bd. 1. Hamburg: Hamber Edition 2006, S. 239-272.

-: India and Ostpolitik. In: Carol Fink / Bernd Schaefer (Hrsg.): Ostpolitik, 1969-1974. European and Global Responses. Washington D.C.: Cambridge University Press 2009, S. 163-181.

-: Indiens sicherheitspolitische Wende zwischen 1962 und 1974. In: Sebastian Buciak / Rüdiger v. Dehn (Hrsg.): Indien und Pakistan - Atommächte im Spannungsfeld regionaler und globaler Veränderungen. Beiträge zur Außen- und Sicherheitspolitik Südasiens. Berlin: Verlag Dr. Köster 2010, S. 93-118.

-: Divided Nations: India and Germany. In: Andreas Hilger / Corinna R. Unger (Hrsg.): India in the World since 1947. National and Transnational Perspectives. Frankfurt a.M.: Peter Lang 2012, S. 300-325.

-: West Germany's South Asia Policy 1947 to 1972. In: Joanne Cho / Eric Kurland / Douglas McGetchin (Hrsg.): Encounters between Germany and Asia in the Twentieth Century. London: Routledge 2014, S. 189-202.

Dehn, Rüdiger v.: Der lange Weg ins „Reich der Mitte“. Amerikanischer Einfluss im indischpakistanischen Krieg vom Dezember 1971. In: Sebastian Buciak / Rüdiger v. Dehn (Hrsg.): Indien und Pakistan - Atommächte im Spannungsfeld regionaler und globaler Veränderungen. Beiträge zur Außen- und Sicherheitspolitik Südasiens. Berlin: Dr. Köster 2010, S. 119-132.

Diettrich, Silke: Plötzlich illegal. In: Deutschlandfunk, 04.08.2018, https://www.deutschlandfunk.de/indien-ploetzlich-illegal.799.de.html?dram:article_id=42467 8 (Zugriff am 08.10.2018).

Dinkel, Jürgen: Die Bewegung Bündnisfreier Staaten. Genese, Organisation und Politik (1927-1992). Berlin / München / Boston: Walter de Gruyter 2015.

Eckert, Andreas: Westdeutsche Entwicklungszusammenarbeit mit Afrika. Ein Blick auf die 1950er bis 1970er Jahre. In: Alexander Galus / Axel Schildt / Detlef Siegfried (Hrsg.): Deutsche Zeitgeschichte - transnational. Göttingen: Wallstein 2015, S. 27-44.

End, Heinrich: Zweimal deutsche Außenpolitik. Internationale Dimensionen des innerdeutschen Konflikts 1949-1972. Köln: Wissenschaft und Politik 1973. 
Engerman, David C.: South Asia and the Cold War. In: Robert J. McMahon (Hrsg.): The Cold War in the Third World. New York: Oxford University Press 2013, S. 67-84.

-: How Nixon and Kissinger Aided Genocide in Bangladesh. In: The Chronicle of Higher Education, 07.10.2013. http://chronicle.com/article/How-NixonKissinger-Aided/142111/ (Zugriff am 08.10.2018).

Franke, Martina: Hoffnungsträger und Sorgenkind Südasien. Westdeutsche Betrachtungen und Begegnungen zwischen 1947 und 1973. Heidelberg: CrossAsia E-Publishing 2017.

Freedman, Lawrence D.: Frostbitten. Decoding the Cold War 20 years later. In: Foreign Affairs 89,2 (März/April 2010). http://www.foreignaffairs.com/articles/66033/lawrence-dfreedman/frostbitten (Zugriff am 08.10.2018).

Freitag, Ulrike: Translokalität als ein Zugang zur Geschichte globaler Verflechtungen. In: H-Soz-Kult, 10.06.2005. https://www.hsozkult.de/hsk/forum/2005-06-001 (Zugriff am 08.10.2018).

- / Oppen, Achim v.: Introduction. „Translocality“: An Approach to Connection and Transfer in Area Studies. In: Dies. (Hrsg.): Translocality. The Study of Globalising Processes from a Southern Perspective. Leiden / Boston: Brill Academic Publishers 2010.

Geyer, Michael: Rezension zu Gunilla Budde / Sebastian Conrad / Oliver Janz (Hrsg.): Transnationale Geschichte. Themen, Tendenzen und Theorien. Göttingen 2006. In: H-Soz-Kult, 11.10.2006. http://www.hsozkult.de/publicationreview/id/rezbuecher-8227 (Zugriff am 08.10.2018).

Görtemaker, Manfred: Die Ursprünge der „neuen Ostpolitik“ Willy Brandts. In: Arnd Bauerkämper / Martin Sabow / Bernd Stöver (Hrsg.): Doppelte Zeitgeschichte. Deutschdeutsche Beziehungen 1945-1990. Bonn: Dietz 1998, S. 44-57.

Greiner, Bernd: Kalter Krieg und „Cold War Studies.“ In: Docupedia-Zeitgeschichte, 11.02.2010, http://docupedia.de/zg/Cold_War_Studies?oldid=84591 (Zugriff am 08.10.2018).

-: Bringing the Cold War Back Home. In: Agnes Bresselau v. Bressensdorf / Elke Seefried / Christian F. Ostermann (Hrsg.): West Germany, the Global South and the Cold War. Berlin / Boston: De Gruyter Oldenbourg 2017, S. 211-220.

Grosser, Pierre: Looking for the Core of the Cold War, and Finding a Mirage? In: Cold War History 15,2 (2015), S. 245-252.

Grünbacher, Armin: Reconstruction and Cold War in Germany. The Kreditanstalt für Wiederaufbau 1948-1961. Burlington: Ashgate 2004.

Guha, Ramachandra: India after Gandhi. The History of the World's Largest Democracy. New York: HarperCollins Publishers 2008.

Gupta, Kulwant Rai / Shukla, Vatsala: Foreign Policy of India, Bd. 1. New Delhi: Atlantic Publishers \& Distributors (P) Ltd. 2009.

Haider-Wilson, Barbara: Humpty Dumpty, die Geschichtswissenschaft und der Pluralismus. Einlassung auf die historische Subdisziplin „Internationale Geschichte.“ In: Barbara Haider-Wilson / William D. Godsey / Wolfgang Müller (Hrsg.): Internationale Geschichte in Theorie und Praxis / International History in Theory and Practice. Wien: Verlag der Österreichischen Akademie der Wissenschaften 2017, S. 9-61.

Hossein, Kamal: Bangladesh. Quest for Freedom and Justice. Dhaka: The University Press Ltd. 2013.

Hubel, Helmut: Weltpolitische Bestimmungsfaktoren im Verhältnis der beiden deutschen Staaten zur Dritten Welt. In: Siegfried Baske / Gottfried Zieger (Hrsg.): Die Dritte Welt und die beiden Staaten in Deutschland. Asperg b. Stuttgart: Edition Meyn 1983, S. 81-92. 
Hüttmann, Jens: Geschichte der innerdeutschen Beziehungen 1945-1989. Berlin: Landeszentrale für politische Bildung Thüringen und Bundesstiftung Aufarbeitung 2012.

Husain, Ishtiaq: 'Heroes of 71: Retaliation' to be released on March 26. In: DhakaTribune, 23.03.2016, https://www.dhakatribune.com/uncategorized/2016/03/23/heroes-of-71-retaliation-to-be-released-on-march-26 (Zugriff am 08.10.2018).

Iqbal, Iftekhar: Review of Srinath Raghavan. 1971. A Global History of the Creation of Bangladesh. In: The American Historical Review 119,5 (2014), S. 1661-1662.

Jacobsen, Hans-Adolf, Gert Leptin, Ulrich Scheuner und Eberhard Schulz (Hrsg.): Drei Jahrzehnte Außenpolitik der DDR. Bestimmungsfaktoren, Instrumente, Aktionsfelder. München / Wien: R. Oldenbourg 1979.

Kaelble, Hartmut: Die Debatte über Vergleich und Transfer und was jetzt? In: H-Soz-Kult, 08.02.2005. http://www.hsozkult.de/article/id/artikel-574 (Zugriff am 08.10.2018).

Käppner, Joachim: Angst vor der Rückkehr des Kalten Krieges. In: Süddeutsche Zeitung, 30.03.2018, https://www.sueddeutsche.de/politik/internationale-krisen-angst-vor-derkaelte-1.3924644 (Zugriff am 08.10.2018).

Kilian, Werner: Die Hallstein-Doktrin. Der diplomatische Krieg zwischen BRD und der DDR 1955-1973. Aus den Akten der beiden deutschen Außenministerien. Berlin: Duncker \& Humblot 2001.

Kinnebrew, Jeanna / Sayward, Amy L.: Making and Keeping the Peace. U.N. Peacekeeping and Refugee Assistance Operations. In: Amy L. Sayward (Hrsg.): The United Nations in International History. London / New York: Bloomsbury 2017, S. 121-146.

Kisch, Egon Erwin: Ein Reporter wird Soldat. In: Schreib das auf, Kisch! Ein Kriegstagebuch. Berlin: Aufbau 2014, S. 307-320.

Knipp, Kersten: Russland: Kalter Krieg reloaded? In: Deutsche Welle, 02.03.2018, https://www. dw.com/de/russland-kalter-krieg-reloaded/a-42790821 (Zugriff am 08.10.2018).

Kulke, Hermann / Rothermund, Dietmar: Geschichte Indiens. Von der Induskultur bis heute. München: C.H.Beck 2006.

Kumar, Kuldeep: India, Russia strive for 'multipolar' world in Trump's 'America first' era. In: Deutsche Welle, 25.05.2018, https://www.dw.com/en/india-russia-strive-for-multipolarworld-in-trumps-america-first-era/a-43930359 (Zugriff am 08.10.2018).

Kupper, Siegfried: Die Tätigkeit der DDR in den nichtkommunistischen Ländern, Bd. 3: Indien, Ceylon, Malediven. Bonn: DGAP 1970.

Kux, Dennis: Estranged Democracies. India and the United States. 1941-1991. New Delhi: Sage Publications 1994.

-: The United States and Pakistan, 1947-2000. Disenchanted Allies. Washington: Johns Hopkins University Press 2001.

Lawrence, Mark Atwood: The Rise and Fall of Nonalignment. In: Robert J. McMahon (Hrsg.): The Cold War in the Third World. New York: Oxford University Press 2013, S. 139-155.

Lorenzini, Sara: East-South relations in the 1970s and the GDR involvement in Africa. In: Max Guderzo / Bruna Bagnato (Hrsg.): The Globalization of the Cold War. Diplomacy and local confrontation, 1975-85. London / New York: Routledge 2010, S. 104-116

Lüthi, Lorenz M.: Non-Alignment, 1961-74. In: Sandra Bott / Jussi M. Hanhimäki / Janick Marina Schaufelbuehl / Marco Wyss (Hrsg.): Neutrality and Neutralism in the Global Cold War: Between or Within the Blocs? Abingdon: Routledge 2017, S. 90-107.

Macdonald, Simon: Transnational History: A Review of Past and Present Scholarship. In: University College London Centre for Transnational History, 2013. https://www.ucl.ac.uk/ centre-transnational-history/objectives/simon_macdonald_tns_review (Zugriff am 08.10.2018). 
Macmillan, Margaret: Nixon and Mao. The Week that Changed the World. New York: Random House 2007.

Malik, Iftikar H.: The History of Pakistan. Westport: Greenwood Press 2008.

Mamoon, Muntassir: The Vanquished Generals and the Liberation War of Bangladesh, aus d. Bengalischen v. Kushal Ibrahim. Dhaka: Somoy Prokashan 2000

Manjapra, Kris: Age of Entanglement. German and Indian Intellectuals across Empire. Cambridge: Harvard University Press 2014.

Mann, Michael: Geschichte Indiens. Vom 18. bis zum 21. Jahrhundert. Paderborn: Ferdinand Schöningh 2005.

-: Geschichte Südasiens. 1500 bis heute. Darmstadt: WBG 2009.

-: Sinnvolle Geschichte. Historische Repräsentationen im neuzeitlichen Südasien. Heidelberg: Draupadi 2009.

Matthies, Volker: Blockfreiheit als Sicherheitspolitik. Die Bewegung der Blockfreien als „größte Friedensbewegung der Geschichte"? München: Weltforum 1983.

-: Die Blockfreien. Ursprünge, Entwicklung, Konzeptionen. Opladen: Leske + Budrich 1985.

McMahon, Robert J.: Cold War on the Periphery. The United States, India and Pakistan. New York: Columbia University Press 1994.

-: Heiße Kriege im Kalten Krieg. In: Bernd Greiner / Christian Th. Müller / Dierk Walter: Heiße Kriege im Kalten Krieg. Studien zum Kalten Krieg, Bd. 1. Hamburg: Hamber Edition 2006, S. $16-34$.

-: On the Periphery of a Global Conflict: India and the Cold War, 1947-1991. In: Andreas Hilger / Corinna Unger (Hrsg.): India in the World since 1947. National and Transnational Perspectives. Frankfurt a.M.: Peter Lang 2012, S. 276-299.

-: Introduction. In: Ders. (Hrsg.): The Cold War in the Third World. New York: Oxford University Press 2013, S. 1-10.

-: Agency, Structure, and Interdependence: Reflections on the Regional and Global Cold Wars. In: Lorenz M. Lüthi (Hrsg.): The Regional Cold Wars in Europe, East Asia, and the Middle East. Crucial Periods and Turning Points. Washington, D.C.: Woodrow Wilson Center Press 2015, S. 18-28.

Middell, Matthias / Naumann, Katja: Global History and the Spatial Turn. From the Impact of Area Studies to the Study of Critical Junctures of Globalization. In: Journal of Global History 5,1 (2010), S. 149-170.

Mišković, Nataša: Introduction. In: Nataša Mišković / Harald Fischer-Tiné / Nada Boškovska (Hrsg.): The Non-Aligned Movement and the Cold War. Delhi - Bandung - Belgrade. London / New York: Routledge 2014, S. 1-18.

Misra, Satish Chand: India and the GDR. A Critical Study of the Problem of Recognition (1954-1972). Berlin (Ost): Humboldt-Universität 1978.

-: India-GDR. Three Decades of Relations. New Delhi: Patriot Publishers 1986.

Möller, Harald: DDR und Dritte Welt. Die Beziehungen der DDR mit Entwicklungsländern. Ein neues theoretisches Konzept, dargestellt anhand der Beispiele China und Äthiopien sowie Irak/Iran. Berlin: Verlag Dr. Köster 2004.

Moses, Dirk A.: Die Vereinten Nationen, humanitäres Engagement und die Menschenrechte. Kriegsverbrecher- und Völkermordprozesse gegen pakistanische Soldaten in Bangladesch, 1971-1974. In: Stefan-Ludwig Hoffmann (Hrsg.): Moralpolitik. Geschichte der Menschenrechte im 20. Jahrhundert, Göttingen: Wallstein 2010, S. 337-367.

Muth, Ingrid. Die DDR-Außenpolitik 1949-1972. Inhalte, Strukturen, Mechanismen. Berlin: Christoph Links 2000. 
Nayar, Baldev Raj: American Geopolitics and India. New Delhi: Manohar Publishers 1976. Niethammer, Lutz: Methodische Überlegungen zur deutschen Nachkriegsgeschichte.

Doppelgeschichte, Nationalgeschichte oder asymmetrisch verflochtene Parallelgeschichte? In: Christoph Kleßmann / Hans Misselwitz / Günter Wichert (Hrsg.): Deutsche Vergangenheiten - eine gemeinsame Herausforderung. Der schwierige Umgang mit der doppelten Nachkriegsgeschichte. Berlin: Christoph Links 1999, S. 307-327.

Nübel, Christoph: Interview mit Hermann Wentker. Fünfter Teil der Reihe „Forschung zum Kalten Krieg - eine Bestandsaufnahme.“ In: Portal Militärgeschichte, 18.07.2016. http:// portal-militaergeschichte.de/wentker_interview (Zugriff am 08.10.2018).

-: Interview mit Sibylle Marti. Sechster Teil der Reihe „Forschung zum Kalten Krieg - eine Bestandsaufnahme.“ In: Portal Militärgeschichte, 01.08.2016. http://portal-militaer geschichte.de/marti_interview (Zugriff am 08.10.2018).

Orton, Anna: India's Borderland Disputes. China, Pakistan, Bangladesh, and Nepal. New Delhi: Epitome Books 2010.

Pai, Nitin: The 1971 East Pakistan Genocide. A Realist Perspective. In: Bangladesh Genocide Archive, 2008. http://www.genocidebangladesh.org/wp-content/uploads/2008/03/ eastpakistangenocide1971-realistperspective1.pdf (Zugriff am 08.10.2018).

Pernau, Margrit: Transnationale Geschichte. Göttingen: Vandenhoeck \& Ruprecht 2011. - / Jordheim, Helge: Global history meets area studies. Ein Werkstattbericht. In: H-Soz-Kult, 14.11.2017. www.hsozkult.de/debate/id/diskussionen-4229 (Zugriff am 08.10.2018).

Prasad, Bimal: Indo-Soviet Relations 1947-1972. New Delhi: Allied Publishers Private Ltd. 1973. Raghavan, Srinath: Between Regional and Global Interests: The Indo-Soviet Treaty of 1971. In: Andreas Hilger / Corinna Unger (Hrsg.): India in the World since 1947. National and Transnational Perspectives. Frankfurt a.M.: Peter Lang 2012, S. 326-345.

-: India as a Regional Power. In: Bruce Jones / Pratap Bhanu Mehta / Waheguru Pal Singh Sidhu (Hrsg.): Shaping the Emerging World. India and the Multilateral Order. Washington, D.C.: Brookings Institution Press 2013, S. 57-62.

-: 1971. A Global History of the Creation of Bangladesh. Cambridge / London: Harvard University Press 2013.

Rogers, William P.: United States Foreign Policy 1971. A Report of the Secretary of State. Washington, D.C.: Department of State 1972.

Romero, Frederico: Cold War Historiography at the Crossroads. In: Cold War History 14,4 (2014), S. 685-703.

Rüger, Jan: OXO: Or, the Challenges of Transnational History. In: European History Quarterly 40,4 (2010), S. 656-668.

Rushdie, Salman: Shame. London: Vintage 1995.

Saikia, Yasmin: Listening to the Enemy: The Pakistan Army, Violence and Memories of 1971. In: Naveeda Khan (Hrsg.): Beyond Crisis. Re-evaluating Pakistan. London / New York / New Delhi: Routledge 2010.

Sargent, Daniel J.: A Superpower Transformed. The Remaking of American Foreign Relations in the 1970s. New York: Oxford University Press 2015.

Saunier, Pierre-Yves: Going Transnational? News from Down Under. In: Historical Social Research 31,2 (2006), S. 118-131.

Schneider, Eberhard: Die Außenpolitik der DDR gegenüber Südasien. Köln: Bundesinstitut für Ostwissenschaftliche und Internationale Studien 1978. 
Schoenborn, Benedikt / Niedhart, Gottfried: Erfurt and Kassel, 1970. In: Kristina Spohr / David Reynolds (Hrsg.): Transcending the Cold War. Summits, Statecraft, and the Dissolution of Bipolarity in Europe, 1970-1990. Oxford: Oxford University Press 2016, S. 15-42.

Sewell, William H.: Logics of History. Social Theory and Social Transformation. Chicago / London: University of Chicago Press 2005.

Sisson, Richard / Rose, Leo E.: War and Secession. Pakistan, India, and the Creation of Bangladesh. Berkeley / Los Angeles / Oxford: University of California Press 1991.

Slobodian, Quinn: Foreign Front. Third World Politics in Sixties West Germany. Durham: Duke University Press 2012.

Smith, Tony. New Bottles for New Wine: A Pericentric Framework for the Study of the Cold War. In: Diplomatic History 24,4 (2000), S. 567-591.

Sommer, Theo: Was Europa von Indien, China und Russland lernen kann. In: Zeit Online, 24.07.2018, https://www.zeit.de/politik/ausland/2018-07/transatlantische-beziehungendonald-trump-angela-merkel-eu-usa (Zugriff am 08.10.2018).

Spanger, Hans-Joachim / Brock, Lothar: Die beiden deutschen Staaten in der dritten Welt. Die Entwicklungspolitik der DDR - eine Herausforderung für die BRD? Opladen: Westdeutscher Verlag 1987.

Struck, Bernhard / Ferris, Kate / Ravel, Jacques: Introduction: Space and Scale in Transnational History. In: The International History Review, 33,4 (2011), S. 573-584.

Tahir-Kheli, Shirin: India, Pakistan, and the United States. Breaking with the Past. New York: Council on Foreign Relations Press 1997.

Unger, Corinna R.: Entwicklungspfade in Indien. Eine internationale Geschichte 1947-1980. Göttingen: Wallstein 2015.

Van Schendel, Willem: A History of Bangladesh. New York: Cambridge University Press 2009. Villaume, Poul / Mariager, Rasmus / Porsdam, Helle: Introduction. The ,Long 1970s': New Perspectives on an Epoch-Making Decade. In: Dies. (Hrsg.): The 'Long 1970s': Human Rights, East-West Détente and Transnational Relations. Abingdon: Routledge 2016.

Voigt, Johannes H.: Die Indienpolitik der DDR. Von den Anfängen bis zur Anerkennung (1952-1972). Köln / Weimar / Wien: Böhlau 2008.

Voß, Klaas: Interview mit Bernd Greiner. Erster Teil der Reihe „Forschung zum Kalten Krieg - eine Bestandsaufnahme."In: Portal Militärgeschichte, 13.06.2016, http://portal-militaergeschichte.de/greiner_interview (Zugriff am 08.10.2018).

Wagner, Christian: Die „verhinderte“ Großmacht? Die Außenpolitik der Indischen Union, 1947-1998. Baden-Baden: Nomos 2005.

Wentker, Hermann: Außenpolitik in engen Grenzen. Die DDR im internationalen System 1949-1989. München: Oldenbourg 2007.

Werner, Michael / Zimmermann, Bénédicte: Vergleich, Transfer, Verflechtung. Der Ansatz der Histoire croisée und die Herausforderung des Transnationalen. In: Geschichte und Gesellschaft. Zeitschrift für historische Sozialwissenschaft 28,4 (2002), S. 607-636.

-: De la comparaison à l'histoire croisée. Paris: Éditions du Seuil 2004.

-: Beyond Comparison. Histoire Croisée and the Challenge of Reflexivity. In: History and Theory 45 (Februar 2006), S. 30-50.

Westad, Odd Arne: Epilogue: The Cold War and the Third World. In: Robert J. McMahon (Hrsg.) The Cold War in the Third World. New York: Oxford University Press 2013, S. 208-219.

-: The Cold War. A World History. London: Allen Lane 2017. 
Wirth, Petra / Janik, Brigitte / Bigler, Luc: Die Spaltung Pakistans und die Gründung der Volksrepublik Bangladesh. Analyse der politischen und sozioökonomischen Entwicklung. In: Vierteljahresberichte 57 (1974), hrsg. v. Forschungsinstitut der Friedrich-Ebert-Stiftung, S. 205-230.

Wolpert, Stanley: Zulfi Bhutto of Pakistan. His Life and Times. New York: Oxford University Press 1993.

Wynbrandt, James: A Brief History of Pakistan. New York: Facts On File 2009.

Xia, Yafeng / Tudda, Chris: Beijing, 1972. In: Kristina Spohr / David Reynolds: Transcending the Cold War. Summits, Statecraft, and the Dissolution of Bipolarity in Europe, 1970-1990. Oxford: Oxford University Press 2016, S. 43-66.

Zamindar, Vazira Fazila-Yacoobali: 1947. Recovering Displaced Histories of Karachi. In: Michel Boivin / Matthew A. Cook (Hrsg.): Interpreting the Sindhi World. Essays on Society and History. Oxford: Oxford University Press 2010. 